\title{
Learning Tools Development in Waste Topic on Students Critical Thinking Skills of Vocational School
}

Sri Ana Yulianti", Badruzsaufari, Muhammad Zaini

Master of Teacher Training In Natural Science Education, Lambung Mangkurat University Indonesia

DOI: $10.36348 /$ jaep.2020.v04i08.004

| Received: 19.08.2020 | Accepted: 27.08.2020 | Published: 30.08.2020

*Corresponding author: Sri Ana Yulianti

\section{Abstract}

This study aims to improve students' thinking skills by developing a learning tool that can improve the critical thinking skills of vocational students using the guided inquiry model. This guided inquiry model was chosen based on the process. This model is able to provide opportunities for teachers to explore critical thinking skills in students. Students learn to apply the process by carrying out problem-based investigations designed to learn science concepts. This research uses the Tessmer development model. The subjects of this research were 3 expert lecturers, the individual trial subjects were 3 students with different academic abilities, the small group trial subjects were $10^{\text {th }}$ grade students with 6 students, the field trial subjects conducted on 10th grade students who numbered 23 people. There are three types of data obtained in this research, namely validity data, practicality data, and effectiveness data. The results of this study are valid learning tools because all components of learning tools are developed in accordance with the guiding principles of development and have been validated by experts. Learning tools are also classified as practical because they are easily implemented and implemented by the teacher in the learning process and get a good response from students. The resulting learning tool is quite effective because the results of students' thinking skills are classified as good, cognitive learning outcomes are classified as good.

Keywords: learning tools development, critical thinking skills, vocational school.

Copyright @ 2020: This is an open-access article distributed under the terms of the Creative Commons Attribution license which permits unrestricted use, distribution, and reproduction in any medium for non-commercial use (NonCommercial, or CC-BY-NC) provided the original author and sources are credited.

\section{INTRODUCTION}

The results of the 2011 Trends in International Mathematics and Science Study (TIMSS) survey data in 2011 showed that the State of Indonesia was included in the 40th of 42 countries with a score of 406 in science skills. Overall, based on the results of a survey for the Program for International Student Assessment (PISA) in 2000-2009, the scientific literacy of Indonesian students is relatively low, in the range of $30-40 \%$. This shows that the scientific ability of Indonesian students is low, moreover its implementation in the form of scientific literacy, is even lower and has not shown an increase [1]. The learning process emphasizes a deep understanding of a learning material that can produce thinking skills [2]. Thinking skills are obtained through activities in the learning process (classroom activity) while the learning process at school tends to be oriented towards cognitive outcomes only. If this is left alone it will make students' thinking skills remain in the lowest position.

Learning outcomes in the learning process are influenced by many components, including the objectives, materials learned, learning strategies, students and teachers as subjects of learning, learning media and supporting the learning process [3]. These components are interrelated with each other so that the weakening of one component will inhibit the achievement of learning objectives to the maximum. Akbar [4] states that learning tools are one of the important aspects of the success of educators in implementing the teaching and learning process and is a sign for an educator in conducting learning activities in the classroom. The learning tool also has a function that is no less important, namely as an evaluation material for educators to find out the extent of achievement of the competency standards that have been submitted.

Learning tools are planning the learning process which is one aspect of creating effective and efficient learning [5]. Planning the learning process that is in accordance with Permendiknas No. 41 of 2007 related to one of its principles for organizing education as a process of civilizing and empowering students that lasts throughout life. One effort that can be done to improve the quality of the learning process is to 
improve learning tools. With the innovation in the learning process, it is expected that students' critical thinking skills will increase. This step is taken through development research (development research). There are two main things in development research: 1) the process of improving the product step by step in producing a prototype and 2) the main elements that will be produced [6]. Development products in this case in the form of learning tools will be trialled through the learning process in the classroom.

The learning process planning can be developed to conform to the SKL and the process standard. The developed product is taught to students during the learning process using learning models. There are several learning models that can be used to improve the learning process, one of which is the inquiry model. This inquiry model was chosen because it provides an opportunity for teachers to explore critical thinking skills. Students are helped to learn and apply the process by carrying out problem-based investigations designed to learn science concepts. The teachers help students generate questions to help the investigation. The inquiry approach is often referred to as "guided discovery". The teacher guides students 'until students discover' the science concepts that have been determined by the teacher [7]. Science learning will be more meaningful if the science learning process is not separated from everyday environmental experiences. Allsop, et al. [8] states that learning that makes students 'experiences and environments in the learning process will greatly help stimulate students' critical thinking skills. Science learning in vocational schools on the topic of waste management is one of the topics that can be learned by utilizing the surrounding environment. Students can interact with the natural environment, conduct investigations/observations of types of waste as well as handling waste.

\section{RESEARCH METHODS}

This study uses the Tessmer development model which consists of five steps. The five steps consist of self-evaluation, expert opinion (expert review), individual trials (one to one), small group trials, and field tests. The subject of this research is the subject of expert trials originating from a team of lecturers who have at least a Masters Education qualification with a total of 3 lecturers. Individual trial subjects are conducted with 3 students who have different academic abilities, small group trial subjects are conducted on $10^{\text {th }}$ grade students (other than individual test subjects) with a total of 6 students, field trial subjects are conducted on $10^{\text {th }}$ grade students (other than subjects individual test and small group test subjects) totaling 23 students.

The types of data obtained in this development research are three groups namely validity data (taken from self-evaluation, expert test, student test), data about practicality (taken from the implementation of lesson plans), and effectiveness data (taken from the results of the learning process teach). The practicality of the tools is obtained through observers (observers) who use observation sheets with the assessment format provided. Effectiveness is obtained by collecting data through Assessment Sheet 1 for Learning Outcomes Test (THB) and Assessment Sheet 2 for Students' Critical Thinking Skills. The data analysis technique in the development of this learning tool is a qualitative descriptive analysis.

\section{RESEARCH RESULTS AND DISCUSSION}

\section{A. Validity of Learning Tools}

The validity of the learning tool is obtained based on the results of validation by three experts with the results of the assessment technique in the form of mode. This activity aims to get input, suggestions and improvements to the learning tools developed including syllabus, lesson plans, teaching materials, Student Worksheet (LKPD), and cognitive assessment sheets. A summary of the results of expert validation on learning tools is summarized in the following table.

Table-1: Syllabus Validation Results

\begin{tabular}{|c|l|c|c|}
\hline \multicolumn{1}{|c|}{ No } & \multicolumn{1}{|c|}{ Validated Aspects } & Score & Validation Criteria \\
\hline Syllabus & & \\
\hline 1 & Systematization of the order of syllabus preparation & 4 & Very valid \\
\hline 2 & Conformity of Basic Competence (KD) with Core Competency (KI) & 4 & Very valid \\
\hline 3 & Coverage of subject matter & 4 & Very valid \\
\hline 4 & $\begin{array}{l}\text { Learning is designed and developed based on KI, KD, and potential } \\
\text { learners }\end{array}$ & 4 & Very valid \\
\hline 5 & Inclusion of activities & 4 & Very valid \\
\hline 6 & Determination of assessment & 4 & Very valid \\
\hline 7 & Determination of media, tools and materials & 3 & Valid \\
\hline 8 & Use of language in accordance with EYD & 3 & Valid \\
\hline 9 & Simplicity of sentence structure & 4 & Valid \\
\hline 10 & Appropriate time allocation used & 3 & Very valid \\
\hline
\end{tabular}


Table-2: RPP Validation Results

\begin{tabular}{|c|l|c|c|}
\hline \multicolumn{1}{|c|}{ No } & \multicolumn{1}{|c|}{ Validated Aspects } & Score & Validation Criteria \\
\hline \multicolumn{1}{|c|}{ Lesson Plan (RPP) } & 4 & Very valid \\
\hline 1 & Complete components RPP & 4 & Very valid \\
\hline 2 & Include the activities of preparing students to study & 3 & Valid \\
\hline 3 & The formulation of learning objectives encourages critical thinking skills & 3 & Valid \\
\hline 4 & Formulation of learning objectives using aspects of ABCD & 3 & Valid \\
\hline 5 & Integrating critical thinking skills in lesson plans & 4 & Very valid \\
\hline 6 & There are preliminary, core, and closing activities & 4 & Very valid \\
\hline 7 & $\begin{array}{l}\text { Match between learning experiences, learning objectives, and time } \\
\text { allocation }\end{array}$ & 4 & Very valid \\
\hline 8 & List 5M activities & 4 & Very valid \\
\hline 9 & Learning steps allow the growth of various life skills & 3 & Valid \\
\hline 10 & Learning activities emphasize the learning experience of students & 4 & Very valid \\
\hline 11 & Utilization of learning resources & 3 & Valid \\
\hline 12 & Use of learning media & 3 & Valid \\
\hline 13 & Utilization of learning models & 3 & Valid \\
\hline 14 & List of tools and materials & 4 & Very valid \\
\hline 15 & Include assessment instruments & 3 & Valid \\
\hline 16 & Include reference sources in the lesson plan & & \\
\hline
\end{tabular}

Table-3: Teaching Material Validation Results

\begin{tabular}{|c|l|c|c|}
\hline No & \multicolumn{1}{|c|}{ Validated Aspects } & Score & Validation Criteria \\
\hline Teaching Material & & \\
\hline 1 & Material relevant to competence & 4 & Very valid \\
\hline 2 & Depth of description is appropriate & 3 & Valid \\
\hline 3 & The material presented is in accordance with scientific truth & 3 & Valid \\
\hline 4 & The material presented in accordance with the latest developments & 3 & Valid \\
\hline 5 & The material presented in accordance with everyday life & 4 & Very valid \\
\hline 6 & Encourage students' curiosity & 3 & Valid \\
\hline 7 & Encourage the interaction of students with learning resources & 4 & Very valid \\
\hline 8 & Encourage students to build their own knowledge & 3 & Valid \\
\hline 9 & Systematic order of matter & 4 & Very valid \\
\hline 10 & Sentence structure according to the level of understanding of students & 3 & Valid \\
\hline 11 & $\begin{array}{l}\text { Making paragraphs/paragraphs according to the level of understanding } \\
\text { of students }\end{array}$ & 3 & Valid \\
\hline 12 & The use of images that support the explanation of the material & 3 & Valid \\
\hline 13 & Presentation of the picture is equipped with a picture description & 3 & Valid \\
\hline 14 & Spelling accuracy & 3 & Valid \\
\hline 15 & Accuracy in terms of use & 3 & Valid \\
\hline 16 & Accuracy in structuring sentences & 3 & \\
\hline
\end{tabular}

Table-4: LKPD Validation Results

\begin{tabular}{|c|l|c|c|}
\hline No & \multicolumn{1}{|c|}{ Validated Aspects } & Score & Validation Criteria \\
\hline Student Worksheet (LKPD) & & \\
\hline 1 & LKPD emphasizes the aspects of the process & 3 & Valid \\
\hline 2 & The accuracy of the cases presented & 3 & Valid \\
\hline 3 & Systematic sequence & 4 & Very valid \\
\hline 4 & The use of images that are interesting and support the material & 3 & Valid \\
\hline 5 & Use of language in accordance with EYD & 3 & Valid \\
\hline 6 & Simplicity of sentence structure & 3 & Valid \\
\hline 7 & The appearance of LKPD is interesting & 4 & Very valid \\
\hline 8 & Efficiency of LKPD in relation to time & 4 & Very valid \\
\hline 9 & Efficiency of LKPD in relation to costs & 4 & Very valid \\
\hline 10 & Efficiency LKPD in relation to personnel & 4 & Very valid \\
\hline
\end{tabular}


Table-5: Learning Outcomes Test Validation Results

\begin{tabular}{|c|l|c|c|}
\hline No & \multicolumn{1}{|c|}{ Validated Aspects } & Score & Validation Criteria \\
\hline Cognitive Assessment & & \\
\hline 1 & Instructions in answering questions are given coherently and clearly & 4 & Very valid \\
\hline 2 & Each item is in accordance with the learning objectives & 3 & Valid \\
\hline 3 & Use of language in accordance with EYD & 4 & Very valid \\
\hline 4 & Simplicity of sentence structure & 3 & Valid \\
\hline
\end{tabular}

Information: 4 (Very valid), 3 (Valid), 2 (Fairly Valid), 1 (Invalid)

Based on the details of the results of the validation of the syllabus, lesson plans, teaching materials, LKPD, and cognitive assessment sheets that have been developed are declared valid with minor revisions. The revised learning kit will be tested in the next stage, which is the individual test phase. Thus the learning tools can be used to determine practicality and effectiveness.

The validity of the learning tools was obtained based on the assessment of 3 expert teams (Expert Review). Validity data is used to measure the feasibility of student worksheets that are developed. Validation is one of the criteria that determines the quality of a product [9]. The validity of the learning tools that have been developed by researchers with the guided inquiry learning model has been validated by experts. The validation of learning tools includes syllabus, lesson plans, teaching materials, LKPD, and cognitive assessment sheets on waste material that are adjusted to the 2013 curriculum. Validation data is used to measure the feasibility of the learning tools developed.

Based on the results of the validator's assessment of the syllabus in Table 4.1. shows that of the 10 indicators assessed, there were 7 indicators that were declared very valid and there were 3 indicators that were declared valid, with minor revisions in the form of suggestions from validators. The syllabus that was developed in accordance with the character of the 2013 curriculum that uses a scientific approach consists of observing, asking, trying, associating, and communicating. This scientific approach is believed to be a bridge in the development of students' knowledge, attitudes and skills, and in accordance with the guided inquiry learning model integrated in the syllabus can help students develop their abilities in the subject matter of waste.

The validator's assessment of the lesson plan shows that of the 16 indicators assessed, there were 8 indicators that were declared highly valid and there were 8 indicators that were declared valid, with minor revisions in the form of suggestions from the validators. The results of the assessment with a very valid category indicate that the components of the preparation of lesson plans have been fulfilled correctly, including school identity, subject identity, class/semester, time allocation, learning objectives, core competencies and basic competencies (KI and KD), achievement indicators, subject matter, learning methods, learning resources, learning steps, and assessment of learning outcomes.

The validator's evaluation of the teaching material showed that of the 16 indicators assessed, there were 4 indicators that were declared very valid and there were 12 indicators that were declared valid, with minor revisions in the form of suggestions from the validator. The development of highly valid teaching materials shows that the material is relevant to learning competence, the pictures are equipped with explanations, and encourage the interaction of students with learning resources.

The validator's assessment of LKPD showed that of the 10 indicators assessed, there were 5 indicators that were declared very valid and there were 5 indicators that were declared valid, with minor revisions in the form of suggestions from the validators. The LKPD that was developed was adjusted to the guided inquiry model. This model was chosen because it can support the achievement of students' critical thinking skills.

Validator's assessment of cognitive assessment showed that of the 4 indicators assessed, there were 2 indicators that were declared very valid and there were 2 indicators that were declared valid, with minor revisions. This shows that the learning tool developed was declared valid with revisions according to the suggestions and criticisms of the validator. This means that learning tools can be a facility to practice students' critical thinking skills.

The learning tool developed is a tool using the guided inquiry model. The results of this validation are in line with Dewi, et al. [10] stating that the learning tool is classified as valid if the learning tool is in accordance with indicators of construct validity and content validity, and is arranged according to the Curriculum. In addition, the research of Jaya, et al. [11] who reported that learning tools that have been developed are suitable to be used if they meet the minimum criteria with valid categories. Apriliyana, et al. [12] also reported that inquiry-based learning tools developed including syllabus, lesson plans, LKPD, student books and evaluation tests showed that learning tools were very suitable for use in the learning process. 
Some studies explain validity as well as feasible. In this study validity based on content validation (which is relevant) which emphasizes the components of the intervention should be based on state-of-the-art knowledge which means the highest achievement in knowledge. Validity is an absolute requirement in development research even though it goes through revision. Because development research there is a guarantee of quality (high quality) at each micro phase [6].

\section{B. Practicality of Learning Tools}

The practicality of learning tools is obtained based on the results of individual tests and the implementation of the lesson plan for learning activities. First of all, an individual test (One-to-One Test) is conducted by 3 students, aiming to check vocabulary confusion or sentences and provide suggestions for learning tools so that learning tools are practical to use. Practicality of the content obtained at the individual test stage using learning tools including teaching materials, LKPD, and cognitive assessment sheets or learning outcomes tests are given to 3 students. Summary of overall assessment results for the readability of learning tools in Table 6 .

Table-6: Readability of Learning Tools from One-to-One Test Results

\begin{tabular}{|c|l|c|c|}
\hline No. & \multicolumn{1}{|c|}{ Components } & Student Rating Score (\%) & Criteria \\
\hline 1 & Teaching Material & 88.89 & Very good \\
\hline 2 & LKPD & 76.19 & Well \\
\hline 3 & Cognitive Assessment Sheet (THB) & 88.89 & Very good \\
\hline
\end{tabular}

Information:

$$
\begin{array}{ll}
81 \%-100 \% & : \text { Very good } \\
66 \%-80 \% & : \text { OK } \\
56 \%-65 \% & : \text { Good Enough } \\
41 \%-55 \% & : \text { Poor } \\
0 \%-40 \% & : \text { Bad }
\end{array}
$$

(Adapted from Nur, 2013)[18]

The implementation of lesson plans is obtained from the observation of partner teachers in teaching learning tools during the learning process. The effectiveness of the lesson plans that are measured to determine the practicality of expectations is done in the process of learning activities at the small group test stage. Small group test was conducted on 6 students of $10^{\text {th }}$ grade in SMK Banjarbaru (excluding individual

\begin{tabular}{|c|c|c|c|c|c|c|}
\hline \multirow[t]{2}{*}{ No } & \multirow[t]{2}{*}{ Activity phase } & \multicolumn{3}{|c|}{ Meeting to- } & \multirow[t]{2}{*}{ Modus } & \multirow[t]{2}{*}{ Category } \\
\hline & & 1 & 2 & 3 & & \\
\hline 1 & Preliminary & 3 & 3 & 4 & 3 & Most of it is done \\
\hline 2 & Main & 3 & 3 & 3 & 3 & Most of it is done \\
\hline 3 & Closing & 3 & 3 & 4 & 3 & Most of it is done \\
\hline
\end{tabular}
test participants). A summary of the overall assessment results for the implementation of the lesson plan in the small group test is included in Table 7 .

Table-7: Summary of Results of RPP Implementation in Small Group Tests

The actual practicality of the learning kit can be seen from the implementation of the lesson plan in the field test. The field test was conducted on 23 students of $10^{\text {th }}$ grades in SMK Banjarbaru (excluding individual and small group test participants). A

\begin{tabular}{|c|c|c|c|c|c|c|}
\hline \multirow[t]{2}{*}{ No } & \multirow[t]{2}{*}{ Activity phase } & \multicolumn{3}{|c|}{ Meeting to- } & \multirow[t]{2}{*}{ Modus } & \multirow[t]{2}{*}{ Category } \\
\hline & & 1 & 2 & 3 & & \\
\hline 1 & Preliminary & 3 & 4 & 4 & 4 & Fully implemented \\
\hline 2 & Main & 3 & 3 & 3 & 3 & Most of it is done \\
\hline 3 & Closing & 3 & 4 & 4 & 4 & Fully implemented \\
\hline
\end{tabular}
summary of the overall assessment results for the implementation of the RPP in the field test can be seen in Table 8.

Table-8: Summary of Results of RPP Implementation in Field Test

Practicality means it is easy to use by users, and can be given and used by all students [13]. Some studies explain the practicality of the same easily understood by students. Students' understanding of learning varies from one another [14], this is because the ability to think differently, the teacher's task is to develop and stimulate thinking skills for all students $[15,16]$. Zaini, et al. [17] reported in the product testing phase that the practicality of the learning instrument had been achieved. This is based on the majority of students who have responded positively to the learning process.

Data from one to one test results can state the level of practicality seen from teaching materials, LKPD, and cognitive assessment sheets that have been 
examined by 3 students. Students who do the One to One test are selected based on ranking data in the class. One to one test data is carried out by providing a readability assessment questionnaire using the guided inquiry model. Assistance from students is used as an improvement in the weaknesses of the tools used in development. Tessmer [13] states that individual test of students at the same time with experts before product trials is intended as an input for revision of learning tools.

Readability questionnaire assessed includes reading content, appearance, type of letter, letter size, linguistic, and level of difficulty. Based on the assessment of teaching material data obtained in Table 4.6, students are able to understand the teaching material given with a score of $88.89 \%$ which is already good. The students stated that the contents, appearance, type of letters and size of the letters in the teaching material were interesting, the readability aspect was good, the description/explanation in the teaching material was not difficult to understand. The LKPD assessment data shows students already understand the given LKPD. Students state that the content, appearance, type of letters and size of letters in LKPD are already interesting, the readability aspect is good. But there is one student who is difficult to understand the purpose of the questions that exist in LKPD. This is because there are some terms that have never been $\mathrm{read} /$ heard by students so that they are difficult to understand and need to be corrected. While the assessment data on cognitive LP shows students already understand the given LKPD. Learners state that the contents, appearance, type of letters and size of letters in LKPD are interesting, aspects of readability are good and are in accordance with students' understanding.

The results of the readability of learning tools in individual trials which include teaching materials, LKPD, and cognitive assessment sheets of subject matter of waste are obtained at least practical categories. So it can be concluded that teaching material, LKPD, and cognitive assessment sheets are said to be feasible and can be used at a later stage. Nur [18] explains the purpose of individual tests that is to correct typos, unclear sentences, missing or unclear clues, inappropriate examples, unknown vocabulary, wrong pictures or non-communicative pages. The learning set of research results has been established practically. This is supported by research data based on the implementation of lesson plans, student responses and teacher responses to learning tools. Jaya, et al. [11] states that the practicality of the tool can be known from the results of observations of the implementation of learning, teacher and student responses to the learning tool.
Practicality in this study was assessed by observers based on the implementation of learning conducted by teachers and students in the class. The ability of teachers to teach tools in the classroom to classroom management carried out in small group tests of preliminary activities, core activities, and closing activities during the three meetings found that most learning outcomes were carried out. The smooth learning process is inseparable from the preliminary activities that open students' insights so that they become motivated to be actively involved in learning, in the core activities in the form of observations that make students active in discussions and work together with friends as a group to solve problems at each meeting, while in the closing activities provide an opportunity for students to verify prior knowledge to avoid misunderstandings of the concept for students. As reported by Schaal, et al. [19] that learning using inquiry models can be one way of providing the experience of prospective teachers in the field. This is in line with the research of Yana 2015 teachers who are proficient in implementing learning by using the guided inquiry model will be easier to guide students in learning because the activities of students are more directed to achieving learning objectives. The teacher is an important role in carrying out learning using the guided inquiry model.

This means that the ability of partner teachers in teaching learning tools using the RPP syntax using guided inquiry learning models that have been scenarized in their implementation is well implemented so that it can be said that the learning tools developed by researchers are practical. Nur [18] the learning process can be made very meaningful by giving students the opportunity to discover or implement the learning themselves through a learning plan.

The results of Sulasih, et al. [20] explained that the tools developed on the basis of inquiry had fulfilled the practical criteria because the implementation of the learning tools showed that all components in each phase of the learning tool were carried out according to the instructions given when the teacher carried out learning in class. Asni, et al. [21] reported that the results of the study of the implementation of the RPP using the guided inquiry learning model had already been implemented with a very good category. The teacher carries out teaching and learning activities in accordance with the planned lesson plans.

\section{Effectiveness of Learning Tools}

The effectiveness of the learning tool is obtained from the results of the field test, which is in the intact class of 23 students. The results of the effectiveness of learning tools include the results of students' critical thinking skills when making observations and student learning outcomes. 
Sri Ana Yulianti et al., J Adv Educ Philos, August, 2020; 4(8): 372-380

\section{Critical Thinking Skills of Students}

Implementing LKPD

Critical thinking skills are measured when students work on LKPD according to the steps of guided inquiry learning. Rupbrik thinking skills measure the following aspects, namely formulating the problem, formulating hypotheses, collecting data, analyzing data, and making conclusions. Data on critical thinking skills in the field test is presented in the form of a Table in the following Table 9.

Table-9: Summary of the Results of Students' Critical Thinking Skills on Field Tests

\begin{tabular}{|c|l|c|c|c|c|c|}
\hline \multirow{2}{*}{ No } & \multirow{2}{*}{ Aspects of Critical Thinking Skills } & \multicolumn{3}{|c|}{ Score } & \multirow{2}{*}{ Mean } & Category \\
\cline { 3 - 5 } & & $\mathbf{1}$ & $\mathbf{2}$ & $\mathbf{3}$ & & \\
\hline 1 & Formulate the problem & 2.96 & 3.26 & 3.30 & 3.17 & Good \\
\hline 2 & Make a hypothesis & 2.91 & 3.04 & 3.04 & 3.00 & Good \\
\hline 3 & Collecting data & 3.17 & 3.35 & 3.35 & 3.29 & Good \\
\hline 4 & Analyze data & 2.83 & 3.09 & 3.09 & 3.00 & Good \\
\hline 5 & Make conclusions & 3.17 & 3.26 & 3.35 & 3.26 & Good \\
\hline
\end{tabular}

Category description: Bad (1-1.75); pretty good (1.76-2.5\%); good (2.6-3.35); very good (3.35-4).

(Source: Modification of Sugiyono, 2014)

Based on Table 9 shows that all aspects of critical thinking measured in the field test are classified as good with an average increase in each meeting. This means that students are able to think critically, from the first meeting to the last meeting. This shows that the tool has achieved effectiveness. Learning tools developed by researchers using guided inquiry models are designed to be a medium capable of training students' critical thinking skills. Beaumont [22] states that critical thinking skills are very necessary and should be owned by students. Duran, et al. [23] explains that inquiry-based learning has a significant positive impact on students' critical thinking skills. The results of assessing students' critical thinking skills are obtained when students work on LKPD according to the syntax of guided inquiry models during the learning process.

Critical thinking skills of students after averaged as a whole have been classified as critical, both at the small group test stage and field test so that learning tools can be said to be effective. Small group test results show scores with a range of $65-71.6 \%$. In this small group test not all students are able to think critically, because in this test students are selected heterogeneously so that there are students who still cannot be trained in their thinking skills. In addition, students have never participated in learning using guided inquiry models in practicing critical thinking skills. But along with learning experiences with guided inquiry students' thinking skills begin to be trained in learning. While the results of the field test show scores in the range of $75.2-80.7 \%$. This achievement is due to the influence of learning tools that are taught with guided inquiry models that make students more active discussions between students in their groups to solve problems that exist in LKPD, so that they can train students' critical thinking skills. The results of students' critical thinking skills are not achieved optimally. This is because so far students have never participated in learning using guided inquiry models that aim to practice critical thinking skills. But along with learning experiences with learning tools using guided inquiry models the critical thinking skills of students begin to be trained in learning, as evidenced by the increasing value of students each meeting.

This study is in line with Lohner, et al. [24] that inquiry learning is effective in requiring students to build and evaluate their own hypotheses, and obtain their own conclusions. This is in line with Lambertus [25] which states that the interaction of fellow students and teachers conducted in this discussion is very influential on the growth and development of students' critical thinking. Matthew, et al. [26] also added that the guided inquiry learning model can give students the opportunity to learn to think critically in the process of scientific performance. Learning using the guided inquiry model can make students interact and become more active in learning activities. Azizmalayeri, et al. [27] report that the guided inquiry model influences students' critical thinking skills in drawing conclusions.

Lambertus [25] explains that learner-centered learning allows discussion. Discussion is an effective way to train and develop critical thinking skills, because: 1) through discussion, students share opinions, think perspectives, and gain experience; 2) through discussion students can consider, reject or accept their own opinions or the opinions of other students to match the answers or opinions of the group; and 3) through discussion as well, students can make adjustments or reduce obstacles between themselves and other students so that they are free to think and act. Interaction between students, students and teachers carried out in this discussion is very influential on the growth and development of students' critical thinking dispositions.

\section{Cognitive Learning Outcomes}

Cognitive learning outcomes are learning outcomes obtained after students participate in learning activities with completeness that has reached the Minimum Mastery Criteria (KKM) set by the school that is equal to 75. Cognitive learning outcomes of students in the field test can be seen in Table 10 . 
Table-10: Summary of Student Learning Outcomes in Field Test

\begin{tabular}{|c|c|c|c|c|c|c|}
\hline Total Students & $\begin{array}{c}\text { Prestest } \\
\text { T }\end{array}$ & $\begin{array}{c}\text { Pretest } \\
\text { TT }\end{array}$ & Postest T & $\begin{array}{c}\text { Postest } \\
\text { TT }\end{array}$ & N-gain & N-gain Category \\
\hline 23 & 3 & 20 & 21 & 2 & 0.7 & High \\
\hline Average & 44.35 & & 81.09 & & & \\
\hline Percentage & $13.04 \%$ & $86.96 \%$ & $91.30 \%$ & $8.70 \%$ & & \\
\hline Miminum Mastery Criteria & \multicolumn{7}{|c|}{ Good } \\
\hline
\end{tabular}

Information:

Minimum completeness criteria (KKM) : 75

Classical completeness $\quad: 80 \%$

$\mathrm{T}$

TT

Description of the N-gain category

$\mathrm{g} \geq 0.7$

$0.7-\mathrm{g} \geq 0.3$

$\mathrm{g}<0.3$

: Mastery

: Not Mastery

(Source: Modifications from Sugiyono: 2014)

Based on Table 10 shows the learning outcomes of students who have met the classical completeness criteria. Students who have completed the posttest are 21 people with an average of 81.09 and have reached the KKM set by the school which is 75 . The N-gain results show a score of 0.7 which is categorized high, so it can be said that the learning tools are developed effectively used in science learning on the topic of waste in $10^{\text {th }}$ grade.

The effectiveness of the learning tools that have been developed are also seen from the cognitive learning outcomes of students. Cognitive learning outcomes of students at the time of the pretest nothing is complete in the small group test or field test. While the posttest activities showed progress which showed the completeness of students in the small group test amounted to 2 people. Whereas 4 other people did not complete. Inability due to this test heterogeneous students are chosen so that there are students who still do not reach completeness. In the posttest field test activities $91.30 \%$ of students were able to achieve classical completeness, although there were still some students who could not achieve mastery learning. The mastery achieved is not maximized because this is because students are still not used to the problem of critical thinking skills, besides that limited time is also an obstacle for students because of the rush in working on the questions.

The results of Kong, et al. [28] that the results of the pre-test/post-test studies show that learning in the environment can help students to build knowledge. The teacher's role in learning is to guide and encourage students to ask questions during the learning process. Brown [29] with the implementation of guided inquirybased learning can improve learning outcomes for students, encourage student involvement to play an active role during learning, provide direct feedback to teachers about students' lack of knowledge, and create a class environment that is well received by participants students.

Progress in learning outcomes is due to internal and external factors that affect student learning outcomes. Internal factors of the students themselves who might have been motivated to learn in understanding the lessons that have been given. While external factors occur due to the influence of learning tools made with guided inquiry learning models. This shows that learning with the guided inquiry model has had a positive impact on student learning outcomes. This is in line with Yarmalinda [30] which states that through the guided inquiry learning model, students can more easily understand the material, so that it will improve student learning outcomes and scientific attitudes. Opara, et al. [31] states learning using inquiry can improve student achievement in biology through inquiry. Students learn to make questions, build explanations, test explanations scientifically and communicate ideas.

\section{CONCLUSION}

1. Learning tools are classified as valid because all components of learning tools that are developed are in accordance with the guiding principles of development and have been validated by experts.

2. Learning tools are categorized as practical because they are easily implemented and implemented by the teacher in the learning process and get a good response from students.

3. The resulting learning tools is quite effective because the results of students' thinking skills are classified as good, cognitive learning outcomes are classified as good.

\section{REFERENCES}

1. Wasis. (2015). "Pembelajaran dan Penilaian Sains Sesuai Tuntutan Kurikulum 2013”. Prosiding Seminar Nasional Tahun 2015 Surabaya, 24 Januari 2015. Program Studi Pendidikan Sains Program Pascasarjana Universitas Negeri Surabaya.

2. Eggen, P., \& Kauchak, D. (2012). Strategi dan Model Pembelajaran Mengejar Konten dan Keterampilan Berfikir. Jakarta: Indeks.

3. Sugandi, A. 2008. Teori Pembelajaran. Semarang: Unnes Press.

4. Akbar. (2012). Peran Guru dalam Mengembangkan Perangkat Pembelajaran PKN di 
SMP Negeri Kota Malang. Skripsi. Fakultas Ilmu Sosial-UM, 1(1) jurnaonline.um.ac.id > Artikel.

5. Soekartiwi. 1995. Meningkatkan Efektivitas Mengajar. Jakarta: Pustaka Jaya.

6. Plomp, T., \& N. Nieveen. (2007). An Introduction to Educational Design Research. Proceedings of the seminar conducted at the East China Normal University, Shanghai (PR China), November 23-26, 2007

7. McBride, W., John, Bhatti, I., Muhammad, Hannan, A., Mohammad., \& Martin, F. (2012). Using an inquiry approach to teach science to secondary school science teacher. Procedia - Sosial and Behavioral Science 46 (2012) 2327 - 2333.

8. Allsopp, D. (2003). Why Students With Special Need Have Diviculty Learning Mathematics and What Teacher To Do Help. Focus on Exceptional Children, 8(8). Hlm. 308-314

9. Akker, J. V. D., dkk. (2006). Educational Design Research. Educational design research seminar organized by the Netherlands Organization for Scientific Research; Program Council for Educational Research (NWO/PROO): Netherlands.

10. Dewi, N. L., Dantes, N., \& Sadia, I. W. (2013). Pengaruh model pembelajaran inkuiri terbimbing terhadap sikap ilmiah dan hasil belajar IPA. Jurnal Pendidikan Dasar, 3(1), 1-10.

11. Jaya, I. M., Sadia, I. W., \& Arnyana, I. B. P. (2014). Pengembangan Perangkat Pembelajaran Biologi Bermuatan Pendidikan Karakter dengan Setting Guided Inquiry untuk Meningkatkan Karakter dan Hasil Belajar Siswa SMP. E-journal Program Pascasarjana Universitas Pendidikan Ganesha Program Studi IPA. 4, 1-12.

12. Apriliyana, U., Herlina, F., \& Rahardjo. (2012). Pengembangan Perangkat Pembelajaran Berbasis Inkuiri pada Materi Pencemaran Lingkungan dalam Upaya Melatih Keterampilan Berpikir Kritis Siswa Kelas X SMA. Journal Unesa. Bio Edu. 1.

13. Tessmer, M. (1993). Planning and conducting formative evaluations. London: Kogan Page.

14. Felder, R. M., \& Brent, R. (2005). How Students Learn, How Teachers Teach, And What Usually Goes Wrong. Effective Teaching. Minnesota: Education Designs, Inc.

15. Fung, Y. H. (2004). Collaborative Online Learning: Interaction Patterns and Limiting Factors. Open Learning, 19(2): 135-149.

16. Saragih, A. H. (2008). Kompetensi Minimal Seorang Guru dalam Mengajar.Tabularasa. Jurnal Pendidikan PPS UNIMED. 1: 23-54.

17. Zaini, M.m dan D. J. Asnida. (2015). Pengembangan Perangkat Pembelajaran IPABiologi Berorientasi Hutan Mangrove Untuk Siswa SMP. Seminar Nasional XII pendidikan Biologi FKIP UNS 08 Agustus 2015. Solo.

18. Nur, M. (2013). Kumpulan Instrumen Penelitian Unggulan Perguruan Tinggi. UNESA: Penelitian Unggulan Perguruan Tinggi.
19. Schaal, S., Matt, M., \& Grübmeyer, S. (2012). Mobile Learning and Biodiversity-Bridging the Gap between Outdoor and Inquiry Learning in PreService Science Teacher education. Procedia Social and Behavioral Sciences, 46, 2327-2333.

20. SULASIH, E. (2010). Pengaruh Implementasi Kurikulum Pendidikan Anak Usia Dini Terhadap Perkembangan Psikologi Anak Usia Dini Di PAUD Aisyiyah Wuled (Doctoral dissertation, STAIN PEKALONGAN).

21. Asni., \& D. Novita. (2015). Penerapan Model Pembelajaran Inkuiri Terbimbing untuk Meningkatkan Keterampilan Proses Siswa pada Materi Laju Reaksi. UNESA Journal of Chemical Education, 4(1), 11 - 17.

22. Beaumont, J. (2010). A Sequence of Critical Thinking Tasks. Tesol Journal, 1(4), 1-22.

23. Duran, M., \& D. Ilbilge. (2016). The Effect of the Inquiry-Based Learning Approach on Student's Critical-Thinking Skills. Eurasia Journal of Mathematics, Science \& Technology Education, 12(12), 2887-2908.

24. Lohner, S., Van Joolingen, W., Savelsbergh, E.R., \& van Hout-Wolters, B. (2005). Students' Reasoning during Modeling in an Inquiry Learning Environment. Computers in Human Behavior, 21(3), 441-461.

25. Lambertus. (2009). Pentingnya Melatihkan Keterampilan Berpikir Kritis dalam Pembelajaran Matematika di SD. Forum Kependidikan, 28(2), 136-142.

26. Matthew, B., \& Kenneth, I. O. 2013. A Study On The Effects Od Guided Inquiry Teaching Method On Students Achievement In Logic. Journal International Researchs, 2(1,10), 135-140.

27. Azizmalayeri, K., Mirshahjafari, E., Sharif, M., Asgari, M., \& Omidi, M. (2012). The impact of guided inquiry methods of teaching on the critical thinking of high school students. Journal of education and Practice, 3(10), 42-47.

28. Kong, S.C., \& So, W. M. W. (2008). A Study Of Building A Resource-Based Learning Environment With The Inquiry Learning Approach: Knowledge of Family Trees. Computers \& Education, 50, 3760.

29. Brown, S. D. (2010). A Process-Oriented Guided Inquiry Approach to Teaching Medicinal Chemistry. American Journal of Pharmaceutical Education, 74 (7), 121.

30. Yarmalinda, D. (2017). Penerapan Guided Inquiry untuk Meningkatkan Kemampuan Berpikir Kritis pada Materi Ekosistem dalam Menghadapi MEA. Prosiding Seminar Nasional Pendidikan Sains PPs Unesa. 14 Januari 2017.

31. Opara, J. A., \& Oguzor, N. S. (2011). Inquiry Instruction Method and The School Science Curriculum. Journal of Social Science, 3(3), 188198. 